\title{
A Scientometric Review of the Current Status and Emerging Trends in Project-Based Learning
}

\author{
Yong-Xin Li, Hui-Min Lai, and Chin-Pin Chen
}

\begin{abstract}
Project-based Learning (PBL) is an effective teaching and learning method, it can promote the performance of the learner to adapt the future work environment. The aim of this study is to provide a perspective on PBL that identify the current status, emerging trends, and certain important themes. By mining the database of Web of Science (WoS), the study had collected 522 references about PBL. By utilizing the application software of WoS and CiteSpace to analyze the data, the study had identified the current status and main emerging trends of PBL. The hottest trends and most popular topics over the past 20 years were discussed. The most popular topics of PBL includes: "the changing global economy", "project ecologies", "flexible environment", "collaborative teamwork", "enhanced graduate attribute", "teacher belief", "engineering design thinking", and "community involvement" etc. Finally, the findings from this study can provide a knowledge map to researchers and practitioners for future work.
\end{abstract}

Index Terms - Project-based learning (PBL), web of science (WoS), CiteSpace.

\section{INTRODUCTION}

In 1870, Project-based Learning (PBL) is a revolutionary product of the American progressive education movement, the main emphasis on learning by doing, the representatives include J. Dewey and F. W. Parker [1]. In 1969, McMaster University in Canada developed a problem-based learning, as a traditional another teaching model of medical education outside of this PBL predecessor [2], [3].

Marx et al. [4] have mentioned that PBL's features include the following. (a) Driving questions: Used to overcome persistent problems and focus on ideas with connections that are not apparent. (b) Investigations: Used to engage learners in planning, designing, and conducting real-world research. (c) Artifacts: Actual results of the process of investigation that represents learner understanding. (d) Collaboration: Learners work in groups. (e) Technological tools: Used to enable more authentic investigations and to foster deeper understanding and learning. Krajcik et al. [3] have identified five essential features of project-based learning, includes: (a) engage students in investigating an authentic question or problem; (b) result in students developing a series of artifacts or products; (c) allow students to engage in investigations; (d) involve students, teachers, and members of society in a community of inquiry; and (e) promote students using cognitive tools.

Manuscript received May 14, 2016; revised July 15, 2016.

Yong-Xin Li and Chin-Pin Chen are with the Department of Industrial Education and Technology, National Changhua University of Education, Taiwan (e-mail: acow0703@gmail.com, iechencp@cc.ncue.edu.tw).

Hui-Min Lai is with the Department of Information Management, Chienkuo Technology University, Taiwan (e-mail: hmin@cc.ctu.edu.tw).
Ultimately, we can perceive PBL as being in line with current trends in higher education.

According to literature reviews show that PBL is an effective teaching and learning method [5]. Through collaborative teamwork, learners develop a positive opinion of the PBL model [6]. PBL promotes learner competencies, such as practical self-learning, critical and self-critical capacity, teamwork, and professional knowledge [7]. The effects of PBL enable learners to increase their performance and belief in their self-efficacy [8]. Additionally, the PBL is a relatively better performance. Such as: Shyu \& Chou (2002) [9] research shows it can effectively enhance the learner's level of thinking; Barak \& Dori [10] research shows that the learners have better performance on their attitudes and knowledge; ChanLin [11] research it can help to develop their skills, comprehensive ability and knowledge; and, Karaman \& Celik [12] research shows that PBL is an effective learning method. Therefore, it is an important issue to explore that the current status and development trends of PBL. According to our review of the literature, we can see that PBL is currently trending as a popular and effective learning method.

Although, Knoll [13] had pointed out that the history of project-based learning (PBL) can be divided into five phases: (a) 1590-1765: the beginnings of project work at architectural schools in Europe; (b) 1765-1880: the project as a regular teaching method and its transplantation to America; (c) 1880-1915: work on projects in manual training and in general public schools; (d) 1915-1965: redefinition of the project method and its transplantation from America back to Europe; and (e) 1965-1997: rediscovery of the project idea and the third wave of its international dissemination, the current status and development trends is lacking. Consequently, we aim to uncover the current trends in PBL.

In this research, we depict the current status and emerging trends in PBL topics between January 1997 and January 2016 using a survey of existing literature in two databases. More specifically, our research aims to (a) reveal the current status of PBL with regard to publications, citations, top authors, top institutions, and top journals; (b) reveal the trends in PBL including the main cluster's structure of references and emerging topical trends; and (c) provide direction for future research when considering research interests in this field.

\section{Methodology AND DatA}

In data mining, we used "project-based learning" as a keyword search within the Web of Science (WoS) database and set the time span to "all years" (covering January 1997 to January 2016). Then, obtained 522 references (Dataset 1) from the WoS Core Collection. WoS and CiteSpace were 
used as our main tools to analyze the current status of PBL and its trends. WoS is able to provide researchers with basic information regarding the most prominent academic literature on the subject, while CiteSpace provides visualization analysis and identifies emerging trends in specific topics of research and its associated literature [14].

Citespace is the most influential application software in the scientific field of visualization analysis [15], [16], to reveal patterns concerning scientific paradigms, including their structural and dynamic properties [17]. Many researchers in different scientific fields have analyzed literature with the help of Citespace. Such as, Zhang et al. [18] utilized Citespace to conduct the development of "social media". Zhang et al. [15] concluded research trends and the overview in the field of "social media-supported knowledge management" with the help of Citespace. Kim [19] conduct the emerging trends and new developments in recommendation systems by utilizing Citespace.

\section{ANALYSIS AND RESULTS}

\section{A. Current Status of PBL}

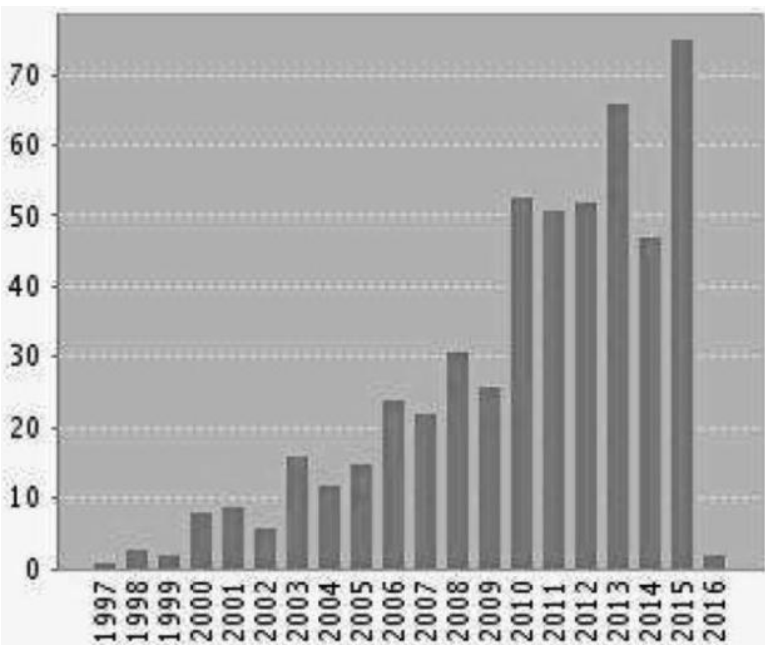

Fig. 1. The number of published papers each year (from January 1997 to January 2016).

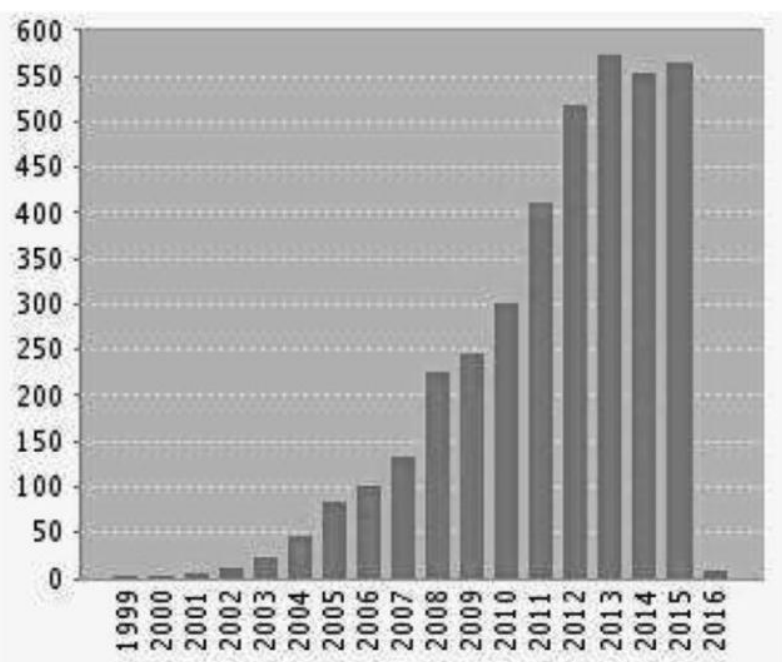

Fig. 2. The number of citations each year (from January 1997 to January 2016).

As Figures 1 and 2 showed, increasing volumes of research were published and cited on "project-based learning" between January 1997 and January 2016. From 1997 to 2009, relatively few papers were published and cited on this topic. However, between 2010 and Jan. 2016, the number of papers published and cited on PBL rose dramatically. In this period, references of PBL in academic publications had increased to $193 \%$ (references $=522,344 / 178 * 100 \%=193 \%$ ), and citations had increased to $329 \%$ (Sum of the Times Cited $=$ $3868,2967 / 901 * 100 \%=329 \%$ ). It appeared that this represents an upward trend in the interest in PBL.

Table I revealed that the top three authors that contributed to the research on PBL were Hou, H. T. $(5 / 522,0.985 \%)$, Kolmos, A. (5/522, $0.985 \%)$, and Fruchter, R. (4/522, $0.766 \%)$.

TABLE I: TOP AUTHORS IN DATASET 1

\begin{tabular}{clcc}
\hline \hline No. & \multicolumn{1}{c}{ Authors } & Records & \% of Total (522) \\
\hline 1 & Hou, H.T. & 5 & $0.958 \%$ \\
2 & Kolmos, A. & 5 & $0.958 \%$ \\
3 & Fruchter, R. & 4 & $0.766 \%$ \\
4 & Lou, S.J. & 4 & $0.766 \%$ \\
5 & Newell, S. & 4 & $0.766 \%$ \\
6 & Scarbrough, H. & 4 & $0.766 \%$ \\
7 & Swan, J. & 4 & $0.766 \%$ \\
\hline \hline
\end{tabular}

Table II revealed that the top three institutions that contributed to the research on PBL during this period were the National Taiwan Normal University (12/522, 2.299\%), the University of Hong Kong (12/522, 2.299\%), and Stanford University $(10 / 522,1.916 \%)$.

TABLE II: TOP INSTITUTIONS IN DATASET 1

\begin{tabular}{|c|c|c|c|}
\hline No. & Organizations & Records & $\%$ of Total (522) \\
\hline 1 & $\begin{array}{l}\text { National Taiwan } \\
\text { Normal University }\end{array}$ & 12 & $2.299 \%$ \\
\hline 2 & $\begin{array}{l}\text { University of Hong } \\
\text { Kong }\end{array}$ & 12 & $2.299 \%$ \\
\hline 3 & $\begin{array}{l}\text { Stanford University } \\
\text { Autonomous }\end{array}$ & 10 & $1.916 \%$ \\
\hline 4 & $\begin{array}{l}\text { University of } \\
\text { Barcelona }\end{array}$ & 8 & $1.533 \%$ \\
\hline 5 & $\begin{array}{l}\text { Technical University } \\
\text { of Madrid }\end{array}$ & 8 & $1.533 \%$ \\
\hline 6 & Indiana University & 7 & $1.341 \%$ \\
\hline 7 & $\begin{array}{l}\text { Arizona State } \\
\text { University }\end{array}$ & 6 & $1.149 \%$ \\
\hline
\end{tabular}

Table III shows that the top three journals publishing research on PBL were the International Journal of Engineering Education (87/522, 16.667\%), IEEE Transactions on Education (40/522, 7.663\%), and the International Journal of Technology and Design Education $(12 / 522,2.299 \%)$

TABLE III: TOP JOURNALS IN DATASET 1

\begin{tabular}{|c|c|c|c|}
\hline No. & $\begin{array}{c}\text { Journals } \\
\end{array}$ & Records & $\%$ of Total (522) \\
\hline 1 & $\begin{array}{l}\text { International Journal of } \\
\text { Engineering Education } \\
\text { (IJEE) }\end{array}$ & 87 & $16.667 \%$ \\
\hline 2 & $\begin{array}{l}\text { IEEE Transactions on } \\
\text { Education }\end{array}$ & 40 & $7.663 \%$ \\
\hline 3 & $\begin{array}{l}\text { International Journal of } \\
\text { Technology and Design } \\
\text { Education }\end{array}$ & 12 & $2.299 \%$ \\
\hline 4 & $\begin{array}{l}\text { International Journal of } \\
\text { Electrical Engineering } \\
\text { Education }\end{array}$ & 11 & $2.107 \%$ \\
\hline 5 & Computers \& Education & 10 & $1.916 \%$ \\
\hline
\end{tabular}

\section{B. Trends of $P B L$}

Table IV listed the top ten most cited references on PBL [6], [20]-[28]. The number one reference was cited 312 times (the 
source is an article written by Dym et al. [20] and was published in the International Journal of Engineering Education in 2015). The second most cited reference was cited 226 times (the source is an article written by Prince \& Felder [21] and was published in the International Journal of Engineering Education in 2015). The other results were as given in the Table IV.

TABLE IV: TOP 10 REFERENCES IN DATASET 1

\begin{tabular}{|c|c|c|c|c|c|}
\hline No. & Author & Year & Source & Freq. & $\begin{array}{l}\text { Source } \\
\text { of Ref. }\end{array}$ \\
\hline 1 & $\begin{array}{l}\text { Dym, C.L. } \\
\text { et al. } \\
\text { Prince }\end{array}$ & 2005 & IJEE & 312 & [20] \\
\hline 2 & $\begin{array}{l}\text { \& Felder, } \\
\text { R.M. }\end{array}$ & 2006 & IJEE & 226 & [21] \\
\hline 3 & Grabher, G. & 2004 & $\begin{array}{l}\text { Organizatio } \\
\text { n Studies } \\
\text { European }\end{array}$ & 151 & [22] \\
\hline 4 & Grabher, G. & 2004 & $\begin{array}{l}\text { Urban And } \\
\text { Regional } \\
\text { Studies }\end{array}$ & 120 & [23] \\
\hline 5 & $\begin{array}{l}\text { Scarbrough } \\
\text {, H. et al. }\end{array}$ & 2004 & $\begin{array}{l}\text { Organizatio } \\
\text { n Studies }\end{array}$ & 103 & [24] \\
\hline 6 & $\begin{array}{l}\text { Windschitl, } \\
\text { M. \& Sahl, } \\
\text { K. }\end{array}$ & 2002 & $\begin{array}{l}\text { American } \\
\text { Educational } \\
\text { Research } \\
\text { Journal }\end{array}$ & 103 & [25] \\
\hline 7 & Raelin, J.A. & 2001 & $\begin{array}{l}\text { Managemen } \\
\text { t Learning }\end{array}$ & 86 & [26] \\
\hline 8 & $\begin{array}{l}\text { Keegan, A. } \\
\text { \& Tumer, } \\
\text { J.R. }\end{array}$ & 2001 & $\begin{array}{l}\text { Managemen } \\
\text { t Learning }\end{array}$ & 72 & [27] \\
\hline 9 & $\begin{array}{l}\text { Liu, T.C. et } \\
\text { al. }\end{array}$ & 2003 & $\begin{array}{l}\text { Journal of } \\
\text { Computer } \\
\text { Assisted } \\
\text { Learning }\end{array}$ & 70 & [28] \\
\hline 10 & $\begin{array}{l}\text { Barak, M. } \\
\text { \& Dori, Y.J. }\end{array}$ & 2005 & $\begin{array}{l}\text { Science } \\
\text { Education }\end{array}$ & 68 & [6] \\
\hline
\end{tabular}

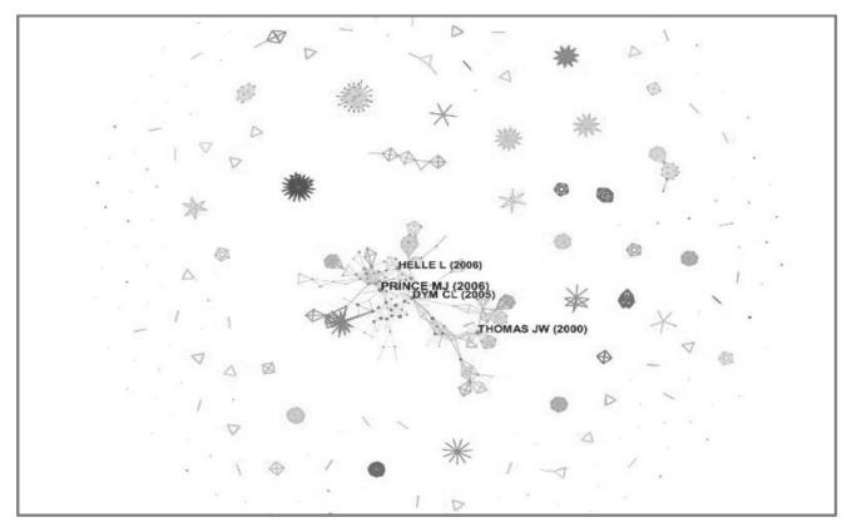

Fig. 3. Structure of PBL authors in dataset 1.

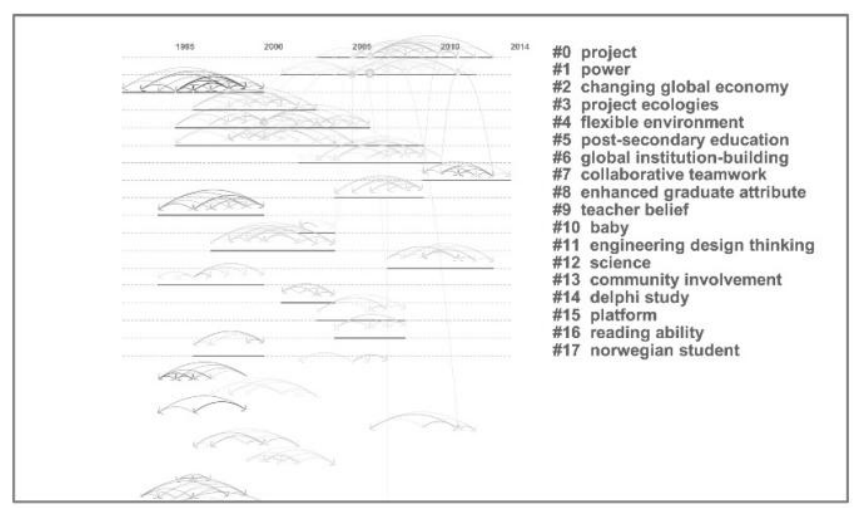

Fig. 4. Development of topics on PBL in dataset 1.

Fig. 3 demonstrated the main cluster of 522 references, revealing that the most cited references are clustered together (Modularity $\mathrm{Q}=0.9467)$. However, many of the references were not clustered, meaning PBL is in an initial or developing stage and lacks a core system (Mean Silhouette $=0.4039$ ). In other word, the modularity Q of 0.9467 is relatively high, which means that the network is reasonably divided into loosely coupled clusters [7]. Then, the mean silhouette score of 0.4039 suggests that the homogeneity of these clusters on average is not very high, but not very low either [7].

Fig. 4 showed that the most popular topics on PBL fell under "project", "power", "changing global economy", "project ecologies", "flexible environment", "post-secondary education", and so on. It also represented the time series analysis and shows the relationships between the cited references.

\section{CONCLUSIONS}

Through an analysis of the data collected from WoS and CiteSpace, there were three new findings on PBL trends. First, between 2010 and Jan. 2016, PBL research has developed rapidly, references of PBL in academic publications have increased to $193 \%$ and citations have increased to $329 \%$. Second, there are clearly different stages in the development of PBL; 2010 is an inflection point, and since then, new trends were formed that can be proven by noting the rise in the number of publications and citations. Third, as a new trend, PBL is apparently still quite young as many of its references are not clustered and it does not have a "core system," meaning PBL is still in a starting/developing stage.

In this study, by using WoS and CiteSpace had provided a perspective on PBL that includes information on its current status and an indication of its emerging trends. PBL's current status was depicted by drawing on information regarding publication and citation trends. In addition, the top cited authors, institutions, and journals were listed. We analyzed the data on 522 references to PBL, which included a quantitative analysis of the "most cited references" and a visual depiction of the main cluster's structure. Moreover, we analyzed the emerging trends on popular PBL topics.

By analyzing the 522 references found on PBL, this study presented an overview of this field for the benefit of future researchers, revealing that the eight most popular trending topics were "changing global economy", "project ecologies", "flexible environment", "collaborative teamwork", "enhanced graduate attribute", "teacher belief", "engineering design thinking", and "community involvement". The findings from this study can provide a knowledge map for researchers and practitioners.

\section{REFERENCES}

[1] W. H. Kilpatrick, "The project method," Teachers College Record, vol. 19, pp. 319-335, 1918

[2] H. S. Barrows, The Tutorial Process, Springfield, Illinois: Southern Illinois University School of Medicine, 1992.

[3] J. S. Krajcik et al., "A collaborative model for helping middle grade science teachers learn project-based instruction," The Elementary School Journal, vol. 94, no. 5, pp. 483-497, 1994.

[4] R. W. Marx et al., "Enacting project-based science," The Elementary School Journal, vol. 97, no. 4, pp. 341-358, 1997.

[5] E. Aydin and E. Kalayci, "Implementing consecutive project-based learning in an antenna and propagation course," International Journal of Electrical Engineering Education, vol. 53, no. 1, pp. 87-96, 2016.

[6] M. Pinho-Lopes and J. Macedo, "Project-based learning in Geotechnics: Cooperative versus collaborative teamwork," European Journal of Engineering Education, vol. 41, no. 1, pp. 70-90, 2016. 
[7] E. I. Aguera et al., "Students integrate knowledge acquisition and practical work in the laboratory," Advances in Physiology Education, vol. 39, no. 3, pp. 209-213, 2015.

[8] I. Bilgin, Y. Karakuyu, and Y. Ay, "The effects of project based learning on undergraduate students' achievement and self-efficacy beliefs towards science teaching," Eurasia Journal of Mathematics Science and Technology Education, vol. 11, no. 3, pp. 469-477, 2015.

[9] H. Y. Shyu and Y. H. Chou, "An instructional design model of web-enhanced project-based learning for elementary and secondary school students," Educational New Thinking and Innovation, Taipei: Psychological Publishing Press, 2002.

[10] M. Barak and Y. J. Dori, "Enhancing undergraduate students' chemistry understanding through project-based learning in an IT environment," Science Education, vol. 89, no. 1, pp. 117-139, 2005.

[11] L. J. ChanLin, "Technology integration applied to project-based learning in science," Innovations in Education and Teaching International, vol. 45, no. 1, pp. 55-65, 2008.

[12] S. Karaman, and S. Celik, "An exploratory study on the perspectives of prospective computer teachers following project-based learning," International Journal of Technology and Design Education, vol. 18 no. 2, pp. 203-215, 2008.

[13] M. Knoll, "The project method: Its vocational education origin and international development," Journal of Industrial Teacher Education vol. 34, no. 3, pp. 59-80, 1997.

[14] C. Chen. (2014). The CiteSpace Manual. http://cluster.ischool.drexel.edu/ cchen/CiteSpace/CiteSpaceManual. pdf

[15] X. Zhang et al., "Mapping development of social media research through different disciplines: Collaborative learning in management and computer science," Computers in Human Behavior, vol. 51, pp. $1142-1153,2015$.

[16] G. Liu, R. Jiang, and Y. Jin, "Sciatic nerve injury repair: A visualized analysis of research fronts and development trends," Neural Regeneration Research, vol. 9, pp. 1716-1722, 2014.

[17] C. Chen, "CiteSpace II: Detecting and visualizing emerging trends and transient patterns in scientific literature," Journal of the American Society for Information Science and Technology, vol. 57, no. 3, pp. 359-377, 2006

[18] X. Zhang et al., "From e-learning to social-learning: Mapping development of studies on social media-supported knowledge management," Computers in Human Behavior, vol. 51, pp. 803-811, 2015.

[19] M. C. Kim and C. Chen, "A scientometric review of emerging trends and new developments in recommendation systems," Scientometrics, vol. 104, pp. 239-263, 2015.

[20] C. L. Dym et al., "Engineering design thinking, teaching, and learning," International Journal of Engineering Education, vol. 94, no. 1, pp. 103-120, 2005.

[21] M. J. Prince and R. M. Felder, "Inductive teaching and learning methods: Definitions, comparisons, and research bases," International Journal of Engineering Education, vol. 95, no. 2, pp. 123-138, 2006.

[22] G. Grabher, "Learning in projects, remembering in networks? Communality, sociality, and connectivity in project ecologies,"
European Urban and Regional Studies, vol. 11, no. 2, pp. 103-123, 2004.

[23] G. Grabher, "Temporary architectures of learning: Knowledge governance in project ecologies," Organization Studies, vol. 25, no. 9, pp. 1491-1514, 2004.

[24] H. Scarbrough, et al., "Project-based learning and the role of learning boundaries," Organization Studies, vol. 25, no. 9, pp. 1579-1600 2004.

[25] M. Windschitl and K. Sahl, "Tracing teachers' use of technology in a laptop computer school: The interplay of teacher beliefs, socia dynamics, and institutional culture," American Educational Research Journal, vol. 39, no. 1, pp. 165-205, 2002.

[26] J. A. Raelin, "Public reflection as the basis of learning," Management Learning, vol. 32, no. 1, pp. 11-30, 2001

[27] A. Keegan and J. R. Tumer, "Quantity versus quality in project-based learning practices," Management Learning, vol. 32, no. 1, pp. 77-98, 2001.

[28] T. C. Liu et al., "Wireless and mobile technologies to enhance teaching and learning," Journal of Computer Assisted Learning, vol. 19, no. 7 , pp. 371-382, 2003

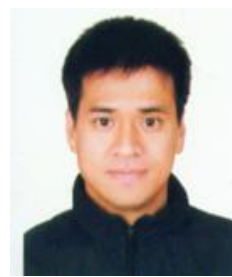

Yong-Xin $\mathbf{L i}$ is an associate researcher at the Department of Business Administration, Tunghai University in Taiwan. And he currently studies at the Department of Industrial Education and Technology at National Changhua University of Education in Taiwan for $\mathrm{PhD}$. His research interests include project-based learning, engineering education and knowledge management.

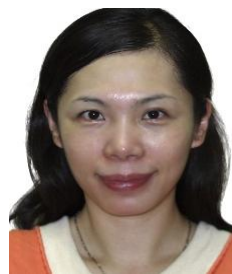

Hui-Min Lai received her $\mathrm{PhD}$ from the Department of Information Management at National Chung Cheng University in Taiwan. She is currently an associate professor at the Department of Information Management of Chienkuo Technology University. Her research interests include decision support systems, knowledge systems, and e-learning systems. She has published papers in Computers \& Education, International Journal of Human-Computer Studies, Computers in Human Behavior, among others.

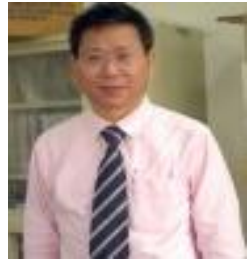

Chin-Pin Chen is a professor of the Department of Industrial Education and Technology at National Changhua University of Education in Taiwan. His current research interests knowledge management, e-learning system, and engineering education. $\mathrm{He}$ has published papers in Computers \& Education, Behaviour \& Information Technology, International Entrepreneurship and Management 